\title{
Pentingnya keterampilan TIK guru PAUD pada abad 21
}

\author{
Shin Prathiwi ${ }^{1}$, Putri Setyaningtyas ${ }^{2}$ \\ ${ }^{1,2}$ Program Studi Pendidikan Anak Usia Dini Universitas Negeri Yogyakarta
}

Email: zhin.chie@gmail.com

\begin{abstract}
ABSTRAK
Teknologi berkembang begitu pesat, di abad 21 ini teknologi bukan lagi menjadi sesuatu yang sulit ditemui. Para milenial mendominasi penggunaan TIK dalam kesehariannya. Tak jarang anak usia dini lebih pandai menerapkan TIK dari pada orang tua atau gurunya. Anak usia dini tergolong generasi digital natif. Generasi digital natif ditandai dengan kemudahan anak mengakses dan berinteraksi dengan peralatan digital sejak dini. Guru PAUD dituntut memiliki kreativitas di dalam mengajar, jika guru masih menggunakan cara lama atau pembelajaran tradisional di abad 21, maka kemungkinan anak kurang antusiasme di dalam kegiatan pembelajaran. Kondisi tersebut, menjadi dasar dilakukan pengamatan. Akan tetapi diperlukan juga subtitusi untuk anak. Pengamatan ini menggunakan metode kualitatif studi kasus. Teknik analisa data yang digunakan yaitu penjodohan pola dan pembuatan penjelasan untuk memaknai kondisi pada TK. Dari pengamatan ini diperoleh hasil bahwa guru TK yang tidak terampil TIK cenderung pasif dan memiliki minat rendah dalam mengasah kemampuan TIK. Hal ini nampak dari wawancara dan observasi yang telah dilakukan pada beberapa narasumber.
\end{abstract}

Kata kunci : Keterampilan TIK; TIK guru PAUD

\begin{abstract}
The technology growth exponentially, therefore, it is not difficult to find it in this century. Millennials dominate ICT on their daily activities. Consequently, many pre-school children more competent on ICT rather than their parents or teachers. Pre-school children classified as digital native generation. It is indicated by ease of access and interaction by digital gadget since early stage. Pre-school teacher must be creative while teaching, if they still use the old-fashioned or traditional teaching style in this century, probably the children pretend to less enthusiastic while they learning. Based on that problems, we observe how pre-school children use the technology, yet also need the substitution to handle it. This observation uses study-case qualitative method. Data analyses technique uses matchmaking pattern and making explanation to interpret the subjects. The result is, the incompetent pre-school teachers pretend to be passive and low interest to hone the ICT skill. It is shown by interview and observation by some respondents.
\end{abstract}

Keywords: ICT Skill, ICT; Pre-school Teacher

(C) 2021 Shin Prathiwi, Putri Setyaningtyas Under the license CC BY-SA 4.0 


\section{PENDAHULUAN}

Abad 21 merupakan era kebangkitan teknologi, informasi dan komunikasi. Teknologi, informasi dan komunikasi (TIK) mengalami perkembangan pesat tiap tahun. Perkembangan TIK mempengaruhi kemajuan diseluruh bidang dan tanda perubahan zaman. Saat ini anak usia dini tergolong generasi digital natif. Generasi digital natif ditandai dengan kemudahan anak mengakses dan berinteraksi dengan peralatan digital sejak dini (Sufa \& Setiawan, 2017). Kemudahan yang semakin meningkat, menyebabkan orang tua dan guru tidak bisa membatasi anak untuk mengenal perangkat lunak (software) dan perangkat keras (hardware). Contohnya: perangkat komputer dan aplikasi yang bervariasi. Selain itu, perkembangan TIK juga mempermudah dalam memperoleh, penyimpanan, mengorganisasi dan menyebarkan informasi atau data (Ismaniati, n.d.). Terlebih untuk Indonesia yang merupakan negara kepulauan (Muhtadi, 2006). Namun belum semua guru PAUD di Indonesia mampu menggunakan perangkat lunak komputer (Sugiarti, 2012; Rohmadheny \& Indratno, 2020).

Hal ini berpengaruh pada pendidikan dalam pembuatan perangkat, pengorganisasian dan proses pembelajaran (Kurniati, Yusnita, \& Sukrilah, 2018; Praudyani \& Rohmadheny, 2019). TIK menjadi hal yang dibutuhkan dalam pendidikan sebagaimana tertuang pada UUD 1945 Pasal 28 Ayat 1 dan Pasal 31 Ayat 1 yang menjelaskan warga negara berhak mendapatkan pendidikan dan manfaat dari ilmu pengetahuan dan teknologi untuk peningkatan kualitas hidup dan kesejahteraan. Keterampilan menggunakan TIK semakin dibutuhkan dalam pengembangan dan pengelolaan pembelajaran yang efektif dan berkualitas. Beberapa negara maju terbukti menggunakan TIK dalam mendukung penyelenggaraan dan peningkatan kualitas pendidikan (Sufa \& Setiawan, 2017). Peningkatan kualitas penyelenggaraan pendidikan menggunakan TIK dapat diketahui dari kenaikan peringkat Human Development Index (HDI) yang telah diukur secara berkala oleh United Nations Development Programme (UNDP) (Muhtadi, 2006; UNDP, 2016).

Penggunaan TIK yang kurang tepat mengakibatkan kemerosotan tingkat kualitas penyelenggaraan pendidikan dalam memanfaatkan TIK yang terjadi setiap tahun yaitu 105 saat 1999 , peringkat 109 untuk tahun 2000, 113 pada 2015 dan 2018 mengalami kemunduran kembali diposisi 116 (UNDP, 2018). Penting peranan keterampilan TIK guru dalam mendukung penyelenggaraan pendidikan. Pemanfaatan TIK dalam pembelajaran di abad 21 ini menjadi hal yang wajib. Guru sebagai fasilitator memiliki peran penting dalam implementasi TIK di dalam persiapan penyelenggaraan dan proses pembelajaran. Menurut sebuah pengamatan, guru profesional abad 21 yaitu mampu menyelesaikan tugas dengan memanfaatkan teknologi digital (Nasution \& Nurhafizah, 2019). Oleh karena itu, penggunaan TIK di sekolah hendaknya 
dimuai dari titik pangkal yang strategis yaitu guru.

Peran guru yang cukup besar dalam memanfaatkan TIK menjadi dasar dilakukan pengamatan terkait topik dengan wawancara kepala sekolah salah satu TK LKMD di Kelurahan Madegondo, Kecamatan Grogol, Sukoharjo. Pengambilan data ini bertujuan membuktikan mengenai kebutuhan keterampilan TIK guru dalam penyelenggaraan pendidikan anak usia dini. Hasil pengamatan dan pengkajian topik ini diharapkan sebagai sarana memperluas wawasan dan menjadi inspirasi pembaca untuk sudi berbagi pengetahuan keterampilan TIK dengan guru PAUD di lingkungan sekitar sebagai upaya meningkatkan kualitas penyelenggaraan pendidikan anak usia dini di Indonesia.

\section{METODE PENELITIAN}

Metode penelitian yang digunakan dalam penelitian ini, adalah kualitatif studi kasus. Metode tersebut dipilih karena tidak memungkinkannya dilakukan penelitian program tahfidz sebagai kondisi terkontrol (penelitian eksperimen). Penelitian ini dilaksanakan pada 1 TK di Madegondo Sukoharjo. Sejumlah 4 guru terlibat dalam penelitian ini. Pengambilan data dilakukan dengan menggunakan lembar wawancara dan observasi pada guru. Sebelum diujikan pada anak, lembar wawancara dan observasi telah melalui uji validitas dan reliabilitas expert judgment. Dari pengujian tersebut, diketahui seluruh butir instrumen memenuhi syarat uji validitas dan reliabilitas of ratings. Setelah melalui uji validitas dan reliabilitas, dilakukan wawancara dan observasi pada guru. Poin wawancara dan observasi mengenai penggunaan TIK dalam penyusunan rencana pembelajaran anak dan penggunaan media sosial sebagai variasi media pada kegiatan anak. Pengamatan dan wawancara poin penyusunan rencana pembelajaran, meliputi: kemampuan penggunaan piranti lunak komputer (Ms. Word dan Excel) dalam menyusun rencana pembelajaran dan mengelola arsip administrasi. Poin penyusunan penggunaan media sosial sebagai variasi media pada kegiatan anak, mencakup: kemampuan penggunaaan media sosial (youtube, ruangguru dan instagram) dalam kegiatan belajar-mengajar anak dan intensitas penggunaan media sosial oleh guru. Kemudian data guru dianalisis menggunakan penjodohan pola dan pembuatan penjelasan. Teknik analisis dipilih dikarenakan jenis data yang tergolong kasus tunggal (hanya melibatkan $1 \mathrm{TK})$.

\section{HASIL DAN PEMBAHASAN}

\section{Hasil Penelitian}

Pengambilan data yang telah dilakukan, diperoleh informasi yaitu mayoritas guru di TK LKMD Kelurahan Madegondo belum memiliki keterampilan yang cukup dalam mengoperasikan perangkat TIK (1 guru terampil, 3 tidak terampil). Hasil pada pengamatan dan wawancara poin penyusunan rencana pembelajaran menunjukan, hanya 1 dari 4 guru yang mampu menggunakan piranti lunak komputer (seperti: Ms. Word dan 
Excel) dalam menyusun rencana pembelajaran (Prosem, RPPM, RPPH) dan mengelola arsip administrasi TK. Pada poin penyusunan penggunaan media sosial sebagai variasi kegiatan anak juga demikian. Hanya 1 guru yang sama, sering mengakses dan menggunakan media sosial (youtube, ruangguru dan instagram) sebagai variasi media dalam kegiatan belajar-mengajar anak.

Guru kurang terampil memiliki minat yang rendah dan cenderung pasif dalam mengasah kemampuan TIK mereka. Meskipun mereka (guru dengan keterampilan TIK rendah) telah diberikan kesempatan pelatihan dan fasilitas komputer di TK oleh sekolah dan Pemerintah Daerah. Piranti komputer yang tersedia, menjadi tidak optimal dalam penyusunan rencana pembelajaran, administrasi kurang terorganisir dan penggunaan media sosial yang rendah. Selain itu, sekolah tidak memiliki operator tetap sehingga memanfaatkan jasa paruh waktu dalam menyelesaikan tugas administrasi dan penyusunan rencana pembelajaran berbentuk softfile.

Rendahnya kualitas guru, menyebabkan pembelajaran PAUD yang dilaksanakan di kelas menjadi monoton, mudah bosan dan kurang menantang sehingga hal tersebut menyebabkan suasana pembelajaran menjadi kurang efektif, inspiratif, dan produktif. Pengambilan data ini dapat disimpulkan, penyelenggaraan pendidikan dengan memanfaatkan TIK dalam menyusun rencana pembelajaran dan variasi kegiatan belajar belum terwujud di TK Kelurahan Madegondo.

\section{Pembahasan}

Hasil pengamatan pada guru kurang terampil memiliki minat yang rendah dan pasif dalam mengasah kemampuan TIK mereka. Sejalan dengan pengamatan lain yang juga memaparkan, kemampuan TIK guru yang rendah mempengaruhi mereka dalam pengetahuan dan kemauan memanfaatkan TIK (Juliasih, 2019).

Namun beberapa hasil pengambilan data bertolak belakang dengan hasil penelitian lain. Penelitian lain menunjukan anak mudah dikontrol, mengenal, dan bijak menggunakan TIK dengan guru yang memiliki keterampilan TIK cukup memadai (Sufa \& Setiawan, 2017). Pada TK LKMD Madegondo, guru menjadi kurang mampu mengontrol variasi kegiatan anak disebabkan kemampuan penggunaan TIK yang rendah. Padahal keterampilan TIK yang dimiliki guru dan anak menciptakan iklim pembelajaran moderat sehingga perkembangan dan pembelajaran anak menjadi lebih cepat, kritis, inovatif dan kreatif ( Muhtadi, 2006; Kurniati, Yusnita, \& Sukrilah, 2018; Nurkolis \& Muhdi, 2020). Begitu pula penguasaan guru dalam Teknologi informasi dan komunikasi sangat berpengaruh kepada penyelenggaraan pembelajaran anak (Kurniati et al., 2018; Muhtadi, 2006).

Keterampilan TIK guru yang rendah di TK LKMD Madegondo, justru semakin menambah beban kerja guru karena harus menyelesaikan tugas penyusunan rencana pembelajaran, arsip dan media secara manual (tulis tangan). Menurut pengamatan, kemahiran terhadap TIK (Ms.Word, Excel dan media sosial) meringankan tugas dan beban kerja guru di 
sekolah ( Azis, 2016; Hapsari, Novitasari, \& Wahyuningsih, 2018; Alzami \& Setiawan, 2019; Nasution \& Nurhafizah, 2019; Rohmadheny \& Indratno, 2020).

Beban tugas yang dimiliki oleh guru, tentu secara tidak langsung berpengaruh pada iklim belajar anak di kelas. Keterampilan TIK membantu guru dalam bertugas dan membantu mewujudkan iklim aktif, variatif dan inovatif pada kegiatan belajar anak (Azis, 2016).

Pemanfaatan teknologi informasi dan komunikasi di lembaga pendidikan khususnya PAUD perlu direncanakan dengan beberapa tahap, diantaranya (Kurniati et al., 2018; Muhtadi, 2006): (1) membuat database;(2) menyusun perangkat pembelajaran dari database dengan memanfaatkan website, aplikasi software atau learning tool;(3) penggunaan TIK dalam evaluasi penyelenggaraan pendidikan yang menunjang mutu pendidikan;(4) menerapkan secara bertahap. Hal ini tentu bertolak belakang dengan kondisi di TK LKMD Madegondo, dimana hanya 1 orang guru yang mampu menyusun perangkat pembelajaran dan mengelola administrasi menggunakan komputer. Keterbatasan kondisi yang terdapat pada TK LKMD Madegondo tersebut, menyebabkan belum tercapaianya penggunaan komputer yang intens pada seluruh arsip evaluasi belajar anak, penyusunan perangkat pembelajaran dan variasi media pada kegiatan anak. Kondisi tersebut disebabkan karena hanya 1 kelas yang memanfaatkan komputer pada kegiatan belajar dan administrasi.

Lembaga pendidikan perlu mengenalkan dan menggunakan teknologi untuk menyesuaikan perkembangan zaman. Perlu dorongan lebih kuat kepada guru dan anak sejak dini mengenal penggunaan prangkat TIK. Pengenalan TIK yang lebih awal guna mempersiapkan mereka pada tahap lanjutan (Nasution \& Nurhafizah, 2019). Pengenalan TIK memerlukan bimbingan orang dewasa, oleh sebab itu guru dibutuhkan untuk mempunyai pengetahuan memadai tentang TIK. Kemampuan TIK pada guru berpengaruh positif pada pemanfaatan TIK di TK (Juliasih, 2019; Windarto, Parlina, \& Wanto, 2019). Pengenalan TIK diharapkan individu memiliki ketrampilan TIK sesuai zaman perkembangannya kelak dan melatih bijak dalam menggunakan TIK.

\section{SIMPULAN}

Pemanfaatan TIK dalam pembelajaran di abad 21 ini seperti menjadi hal yang wajib. Guru sebagai fasilitator memiliki peran penting dalam implementasi TIK di dalam pembelajaran. Oleh karena itu, penggunaan TIK di sekolah hendaknya dimulai dari titik pangkal yang strategis yaitu guru. Perlunya pelatihan implementasi TIK dalam pembelajaran secara kontinu, supaya guru terbiasa dalam menggunakannya. Karena latihan secara kontinu lebih efektif dari pada latihan dengan intensitas waktu yang lama tetapi intensitas latihannya tidak secara kontinyu. Peran TIK cukup besar bagi guru, yakni membantu dalam tugas administratif, menentukan materi, metode dan media pembelajaran yang kreatif, aktif, dan inovatif sehingga meringankan tugas serta dapat meningkatkan minat 
belajar anak. Dibutuhkan keterampilan dan pengetahuan yang memadai bagi guru tentang pengimplementasian TIK di dalam pembelajaran. Pemanfaatan TIK di dalam pembelajaran dapat diterapkan melalui aplikasi (misalnya: macromedia flash) atau software learning tool (misalnya: youtube, power point). Mengenalkan TIK pada anak usia dini, diharapkan dapat menjadikan anak lebih bijak dalam menggunakan TIK.

\section{REFERENSI}

Alzami, F., \& Setiawan, A. (2019). IbM Pemanfaatan Microsoft Word dalam Tata Kelola Pelaporan bagi Pengajar PAUD Korwilcam Jambu. Abdimasku: Jurnal Pengabdian Masyarakat, 2(2), 108-113. https://doi.org/10.33633/ja.v2i2.50

Azis, W. A. (2016). Analisis Kualitatif Pemanfaatan Komputer dalam Proses Pembelajaran Anak Usia Dini. Tunas Siliwangi, 2(2), 26-42.

Hapsari, A., Novitasari, R., \& Wahyuningsih, H. (2018). Pelatihan Literasi Sumber dan Bahan Belajar di Internet bagi Guru PAUD di Kecamatan Ngaglik, Sleman. Jurnal Pengabdian Pada Masyarakat, 3(2), 135-140. https://doi.org/10.30653/002.201832.61

Ismaniati, C. (n.d.). Penggunaan teknologi informasi dan komunikasi dalam peningkatan kualitas pembelajaran.

Juliasih, A. (2019). Pengaruh program pelatihan komputer dasar terhadap kemampuan pendidik PAUD dalam pemanfaatan TIK di PKBM Sukamulya, Kelurahan Sukamulya, Bandung. Universitas Pendidikan Indonesia.

Kurniati, Yusnita, I., \& Sukrilah, R. (2018). Pemanfaatan multimedia dan pemilihan konten bahan ajar multimedia pada pendidikan anak usia dini. In Prosiding Seminar Nasional Teknologi Pendidikan (pp. 1-10).

Muhtadi, A. (2006). Pemanfaatan teknologi informasi untuk meningkatkan kualitas dan efektifitas pendidikan.

Nasution, N., \& Nurhafizah, N. (2019). Profesionalisme guru anak usia dini era digital. Jurnal Pendidikan Tambusai, 3(2), 666-675.

Nurkolis, N., \& Muhdi, M. (2020). Keefektivan Kebijakan E-Learning berbasis Sosial Media pada PAUD di Masa Pandemi Covid-19. Jurnal Obsesi : Jurnal Pendidikan Anak Usia Dini, 5(1), 212. https://doi.org/10.31004/obsesi.v5i1.535

Praudyani, A. V. R., \& Rohmadheny, P. S. (2019). Pelatihan pemanfaatan aplikasi microsoft office dalam pembelajaran sebagai upaya peningkatan profesionalisme bagi guru PAUD di PCA Mantrijeron. Seminar Nasional Hasil Pengabdian Kepada Masyarakat Universitas Ahmad Dahlan, (September), 711-718.

Rohmadheny, P. S., \& Indratno, T. K. (2020). Dampak pelatihan penyusunan laporan perkembangan anak berbantuan aplikasi e-report bagi guru PAUD. In Seminar Nasional Hasil Pengabdian kepada Masyarakat (pp. 775-782).

Sufa, F. F., \& Setiawan, H. Y. (2017). Analisis kebutuhan anak usia dini usia 4-6 tahun pada pembelajaran berbasis komputer anak usia dini. Research Fair UNISRI, l(1), 14-31.

Sugiarti, Y. (2012). Pendayagunaan Teknologi Informasi Dan Komunikasi Dalam Meningkatkan Kompetensi Guru Pendidikan Anak Usia Dini (Paud). Jurnal Teknodik, 16(1), 45-58. Retrieved 
HaL. 1-4

from

https://jurnalteknodik.kemdikbud.go.id/in dex.php/jurnalteknodik/article/view/7/7

UNDP. (2016). Human Development Report 2016 Human Development for Everyone.

Windarto, A. P., Parlina, I., \& Wanto, A.

(2019). PKM : Guru-Guru PAUD “ Melek
" Teknologi Kabupaten Simalungun dihindari dan pungkiri . Di zaman teknologi yang serba instan diharapkan untuk tidak gaptek mulai Arahan normatif tersebut yang menyatakan bahwa tenaga pendidik dalam hal ini sebagai agen pembe, 1(1), 337-343. 